\title{
PENILAIAN KEPUASAN PELANGGAN DENGAN APLIKASI SURVEI PADA PDAM KOTA BENGKULU
}

\author{
Khairil', Ade Dwi Syafutra² \\ Universitas Dehasen Bengkulu \\ E-mail: khairi@unived.ac.id
}

Informasi Naskah:

Diterima:

16 April 2021

Diterbitkan:

3 Juni 2021

\begin{abstract}
Customer satisfaction is a major reason in the service or goods business. The company will get a big profit if the customer is satisfied with the ideal service provided. The purpose of this study was to find the level of satisfaction of the PDAM's performance on customer service by making an online satisfaction survey application. The research method used is system requirements analysis, designing system requirements, coding translating the system with a programming language, implementing the system and maintaining any changes to the system. The results of the study show that the satisfaction survey application can make it easier for customers to send complaints about the service quality of PDAM Kota Bengkulu. With the PDAM polling application, it is faster to take action according to complaints from customers.
\end{abstract}

Keyword: Satisfaction, Application, Survey

\begin{abstract}
Abstrak: Kepuasan pelanggan merupakan faktor utama dalam bidang usaha jasa ataupun barang. Perusahaan akan mendapat keuntungan yang besar apabila pelanggan merasa puas terhadap pelayanan optimal yang diberikan. Tujuan dari penelitian ini adalah untuk mengetahui tingkat kepuasan kinerja PDAM terhadap layanan pelanggan dengan membuat aplikasi survei kepuasan secara online. Metode penelitian yang dilakukan adalah analisis kebutuhan sistem, mendesain kebutuhan sistem, koding menerjemahkan sistem dengan Bahasa pemrograman, implementasi sistem dan pemeliharan jika ada perubahan pada sistem. Hasil dari penelitian menunjukan bahwa aplikasi survei kepuasan dapat mempermudah pelanggan dalam menyampaikan keluhannya tentang kualitas pelayanan PDAM Kota Bengkulu. Dengan aplikasi polling PDAM lebih cepat mengambil Tindakan sesuai keluhan dari pelanggan.
\end{abstract}

Kata Kunci: Kepuasan, Aplikasi, Survei

\section{PENDAHULUAN}

Dengan cepatnya perkembangan peradaban manusia, salah satunya diakibatkan oleh proses penyampaian informasi yang berjalan begitu lancar. Dijaman yang serba modern segala macam infromasi dengan mudah dapat diperoleh melalui berbagai media contohnya untuk media non elektronik adalah Koran dan majalah, sedangkan media elektronik adalah PC/Laptop yang dilengkapi dengan jaringan internet.
Tanpa terhalang jarak dan waktu semua informasi tersebut dengan cepat diterima kapanpun dan dimanapun.

Dalam meningkatkan kualitas pelayanan pada perusahaan/instansi pemerintah, dibutuhkan sarana dan prasarana yang mendukung dalam proses pelayanan yang diberikan. Dimana perlu adanya perlakuan yang tepat melalui input, proses, sampai kepada output dari pelayanan yang diberikan. Hubungan dan komunikasi 
yang baik dengan konsumen sangat dibutuhkan dalam upaya menjaga kelangsungan proses pelayanan yang berkesinambungan.

Salah satu sistem yang diperlukan untuk suatu perusahaan yang menyediakan pelayanan bagi masyarakat seperti Perusahaan Daerah Air Minum (PDAM) Kota Bengkulu yaitu aplikasi survei untuk meninjau kinerja suatu Perusahaan tersebut.

Namun demikian, permasalahan di PDAM Kota Bengkulu berkaitan dengan Kepuasan pelanggan yang ada saat ini, belum bisa diketahui apakah pelanggan sudah merasa cukup dengan pelayanan Perusahaan Daerah Air Minum (PDAM) Kota Bengkulu atau malah sebaliknya pelanggan belum cukup dengan pelayanan Perusahaan Daerah Air Minum (PDAM) Kota Bengkulu yang sudah diberikan ke pelanggan. Karena itu perlu adanya aplikasi survei kepuasan untuk memastikan pelanggan puas atau tidak puas dengan pelayanan yang diberikan.

Adanya sistem survei kepuasan yang dikenal sebagai suatu metode pengumpulan data yang fokus pada pandangan atau pendapat pelanggan mengenai suatu pelayanan yang diberikan perusahaan.

Tujuan dari penelitian ini adalah untuk membantu mengetahui kepuasan pelanggan terhadap kinerja perusahaan daerah air minum kota Bengkulu. Dan Aplikasi yang dibangun dapat memberikan kemudahan/efesiensi waktu bagi pengguna aplikasi.

Oleh karena itu dibutuhkan suatu aplikasi survei online yang dapat membantu PDAM Kota Bengkulu dalam melakukan survei kepuasan layanan PDAM kepada pelanggan, dimana aplikasi ini dapat diakses darimana saja dan kapan saja karena terhubung dengan internet. Namun tidak semua yang dapat memberikan penilaian, karena hak akses dibatasi hanya untuk pelanggan yang terdaftar di PDAM Kota Bengkulu yang dapat memberikan penilaian terhadap survei.

\section{TINJUAN PUSTAKA}

a. Pengertian Perancangan

Perancangan Menggambarkan rencana umum suatu kegiata rancangan proyek dan aktivitas-aktivitas khusus yaitu teknik atau metode-metode dalam merancang sesuatu. Adapun tujuan dari strategi perancangan adalah memberikan kepastian apakah aktivitasaktivitas tersebut benar-benar realistic dengan batasan waktu dan sumbersumber yang telah diterapkan. Beradasarkan tujuan inilah perancang akan bekerja dalam melakukan perancangan (Arif , 2016: 2).

b. Pengertian Aplikasi

Menurut Nazrudin (2012 : 9) "aplikasi adalah suatu sub kelas perangkat lunak komputer yang memanfaatkan kemampuan komputer langsung untuk melakukan suatu tugas yang diinginkan pengguna. Biasanya dibandingkan dengan perangkat lunak sistem yang mengintegrasikan berbagai kemampuan komputer, tapi tidak secara langsung menerapkan kemampuan tersebut untuk mengerjakan suatu tugas yang menguntungkan pengguna. Contoh utama perangkat lunak aplikasi adalah pengolah kata, lembar kerja, dan pemutar media.

Beberapa aplikasi yang digabung bersama menjadi suatu paket kadang disebut sebagai suatu paket atau suite aplikasi (application suite). Contohnya adalah Microsoft Office dan Open Office.org, yang menggabungkan suatu aplikasi pengolah kata, lembar kerja, serta beberapa aplikasi lainnya. Aplikasiaplikasi dalam suatu paket biasanya memiliki antarmuka pengguna yang memiliki kesamaan sehingga memudahkan pengguna untuk mempelajari dan menggunakan setiap aplikasi. Sering kali, aplikasi ini memiliki kemampuan untuk saling berinteraksi satu sama lain sehingga menguntungkan pengguna. Contohnya, suatu lembar kerja dapat dibenamkan dalam suatu dokumen pengolah kata walaupun dibuat pada aplikasi lembar kerja yang terpisah. 
c. Pengertian Polling (Survey)

Dalam Polling (Survey), infomrasi yang dikumpulkan dari responden melalui kuesioner, umumya Polling (Survey) di batasi pada penelitian dengan data yang dikumpulkan dari sampel untuk mewakali seluruh populasi. Hal ini berbeda dengan sensus yang informasinya dikumpulkan dari seluruh populasi. Dengan demikian penelitian survey adalah penelitian yang mengambil sampel dari satu populasi dan menggunakan kuesioner sebagai alat pengumpulan data (Diana, 2017: 7)

d. Pengertian Kepuasan Pelanggan (Konsumen)

Menurut Indrasari (2019: 84) Kepuasan Pelanggan adalah "suatu keadaan emsional, reaksi pasca pembelian mereka dapat berupa kemarahan, ketidakpuasan, kejengkelan, netralitas, kegembiraan atau kesenangan".

Tidak mengherankan bahwa perusahaan telah menjadi terosebsi dengan kepuasan pelanggnan, mengingat hubungannya langsung dengan kepuasann pelanggan, pangsa pasar dan keuntungan.

e. Pengertian Web

Menurut Bekti (2015:35) menyimpulkan bahwa: Website merupakan kumpulan halaman-halaman yang digunakan untuk menampilkan informasi teks, gambar diam atau gerak, animasi, suara, dan atau gabungan dari semuanya, baik yang bersifat statis maupun dinamis yang membentuk satu rangkaian bangunan yang saling terkait, yang masing-masing dihubungkan dengan jaringan-jaringan halaman.

Menurut Rahmadi (2013:1) "website (lebih dikenal dengan sebutan situs) adalah sejumlah halaman webyang memiliki topik saling terkait, terkadang disertai pula dengan berkas-berkas gambar, video atau jenis-jenis berkas lainnya.".

f. Pengertian PHP

Menurut Raharjo dan Heryanto (2012: 41) PHP adalah "salah satu bahasa pemograman skrip yang dirancang untuk membangun aplikasi web. Ketika dipanggil dari web browser, program yang ditulis dengan php akan di-parsing didalam web server oleh interpreter PHP dan diterjemahkan kedalam dokumen HTML"

Menurut Nugroho (2014: 153), PHP (hypertext Preprocessor) adalah "bahasa program yang digunakan untuk membuat aplikasi berbasis web (website, blog, atau aplikasi web)"

g. Skala Pengukuran

Dalam kuesioner ini menggunakan skala likert sebagai pengukuran variabelnya. Dengan skala likert, maka variable yang akan diukur dijabarkan menjadi indicator variable. Kemudian indicator tersebut dijadikan sebagi titik tolak untuk menyusun item-iten instrument yang dapat berupa pertanyaan atau pernyataan ( Sugiyono, 2012:133).

h. MYSQL

MYSQL adalah sebuah perangkat lunak pembuat database yang bersifat terbuka atau open source dan berjalan di semua platform baik Linux maupun sistem operasi Windows, MySQL merupakan program pengaksesan database yang bersifat network sehingga dapat digunakan untuk aplikasi multi user atau pengguna banyak (Kadir, 2014:218)

Menurut MADCOMS (2016:111) "MYSQL adalah sistem manajemen Database SQL yang bersifat Open Source dan paling popular saat ini. Sistem Database MYSQL mendukung beberapa fitur seperti multithreaded, multi-user dan SQL Database managemen system (DBMS)".

i. XAMPP Control Panel

Menurut Nugroho (2014:112) XAMPP adalah paket program web lengkap yang dapat dipakai untuk belajar pemrograman web, khususnya PHP dan MYSQL, XAMPP adalah perangkat lunak bebas, yang mendukung banyak sistem operasi, merupakan kompilasi dari beberapa program. Fungsinya adalah sebagai server yang berdiri sendiri (localhost), yang terdiri atas program Apache HTTP Server, MySQL database dan penerjemah bahasa yang ditulis dengan bahasa pemrograman PHP dan Perl. Bagian penting dari XAMPP yang biasa digunakan :

P-ISSN No. : 1978-8819 
1. Htdoc adalah folder tempat meletakkan berkas-berkas yang akan dijalankan, seperti berkas PHP, HTML, dan skrip lain.

2. phpMyAdmin merupakan bagian untuk mengelola basis data MySQL yang ada dikomputer. Untuk membukanya, buka browser lalu ketikkan alamat

http;//localhost/phpMyAdmin,

maka akan muncul halaman phpMyAdmin

3. Kontrol panel yang berfungsi untuk mengelola layanan (service) XAMPP. Seperti menghentikan (stop) layanan, ataupun memulai (start).

j. PhpMyAdmin

Menurut MADCOMS (2016:109) "PHP (Hypertext Preprocessor) adalah bahasa script yang dapat ditanamkan atau disisipkan ke dalam HTML. PHP banyak dipakai untuk membuat program situs web dinamis". PHP dapat digunakan dengan gratis (free) dan bersifat Open Source. PHP dirilis dalam lisensi PHP license. Untuk membuat program PHP kita diharuskan untuk menginstal web server terlebih dahulu.

k. Basis Data

Menurut Pahlevi (2013: 1) Basis data adalah sekumpulan data yang saling berhubungan secara logis dan terorganisir dengan baik. Kumpulan data tersebut yang saling berhubungan yang disimpan secara bersama sedemikian rupa dan tanpa pengulangan (redudansi) yang tidak perlu, untuk memenuhi berbagai kebutuhan. Kumpulan file/tabel/arsip yang saling berhubungan yang disimpan dalam media penyimpanan elektronis.

Dari pengertian diatas bisa diambil suatu pengertian yang lebih sederhana yaitu basis data adalah kumpulan informasi yang di simpan didalam komputer secara sistematik dan dapat diperiksa menggunakan suatu program komputer untuk memperoleh informasi dari basis data tersebut. Nama lain dari basis data adalah pangkalan data atau Database.

\section{METODOLOGI PENELITIAN}

Metode menjelaskan rancangan kegiatan, ruang lingkup atau objek, bahan dan alat utama, tempat, teknik pengumpulan data, definisi operasional variabel penelitian, dan teknik analisis.

\section{HASIL PENELITIAN DAN PEMBAHASAN}

Aplikasi kepuasan berbasis online ini didesain khusus untuk pelanggan PDAM dalam meningkatkan kepuasan layanan PDAM terhadap pelanggan.

Hasil dari aplikasi survei kepuasan pelanggan ini terdiri dari :

a. Tampilan Hasil Survei

Admin bisa melihat hasil survey pelanggan yang telah mengisi survey tersebut, menu ini memisahkan hasil jawaban pelanggan pergrup, yang menampilkan pertanyaan, isi jawaban, persentase jawaban, dan mempunya tombol print apabila admin ingin mengeprint untuk di sajikan sebagai berkas laporan yang akan diserahkan ke kabag umum untuk di menganalisa.

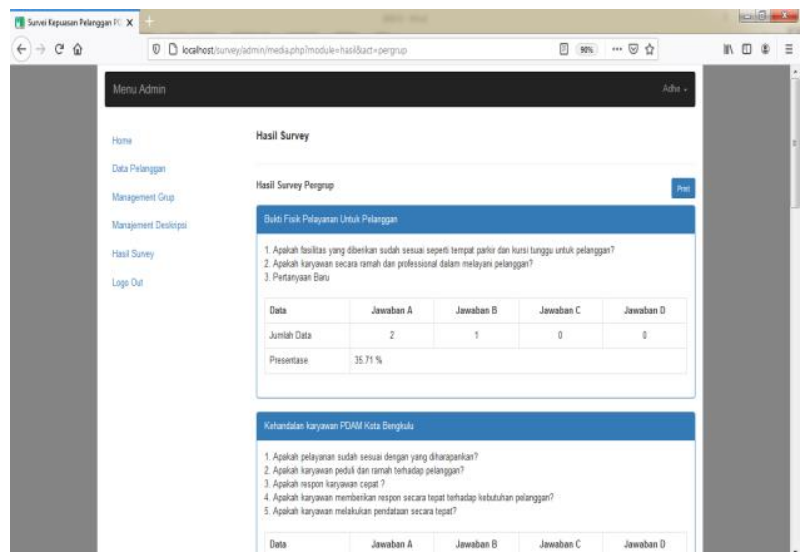

Gambar 1. Tampilan Hasil Survei

b. Tampilan Grafik Hasil Survei Admin bisa melihat seluruh hasil survey yang telah diisi oleh pelanggan dalam bentuk grafik 


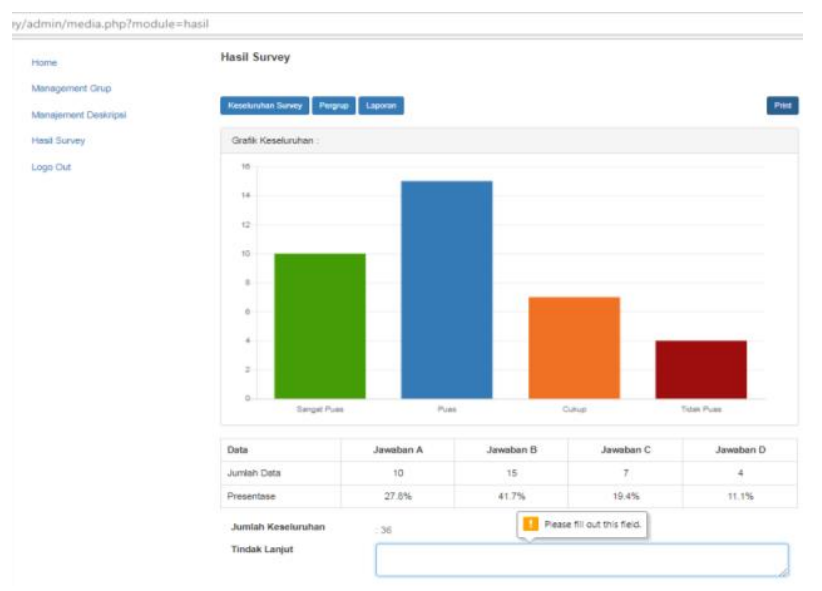

Gambar 2. Grafik hasil Survei

c. Tampilan Laporan Hasil Survei

Admin juga dapat membuat laporan hasil survei, pada laporan tersebut terdapatjawaban yang di isi oleh per pelanggan.

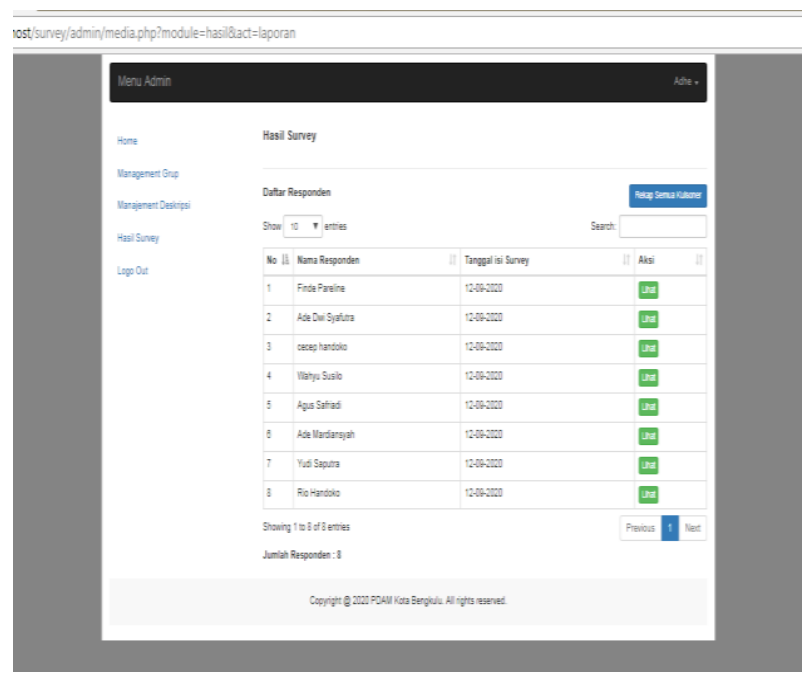

Gambar 3. Laporan Jawaban hasil survei pelanggan

d. Laporan Rekap Hasil Survei

Rekap hasil survei dapat diprint untuk dilaporkan ke kabag umum.

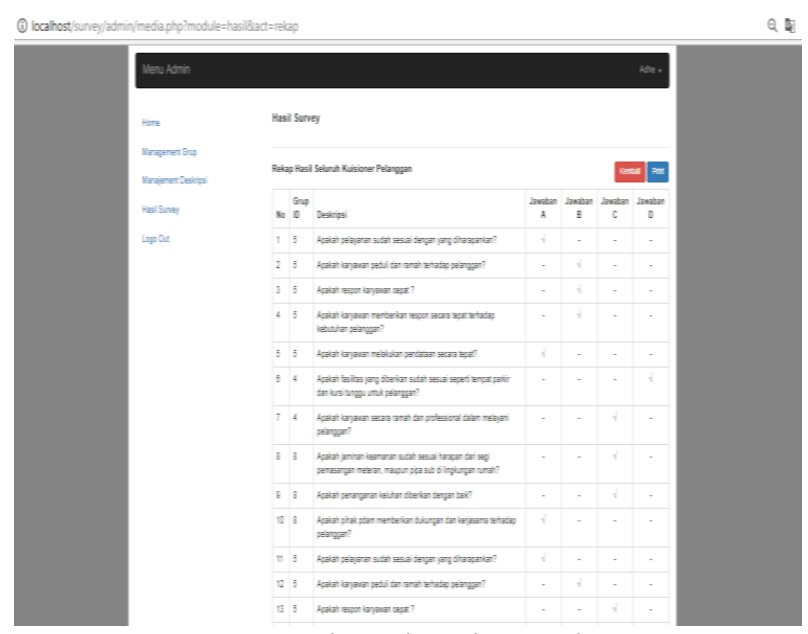

Gambar 4. Rekapitulasi hasil Survei Pelanggan

Pengujian dilakukan dengan metode Blackbox testing, metode ini adalah salah satu metode pengujian perangkat lunak yang berfokus pada sisi fungsionalitas, khususnya pada input dan output aplikasi (apakah sudah sesuai dengan apa yang diharapkan atau belum). Tahap pengujian yang dilakukan pada penelitian ini antara lain :

a. Pengujian menu pelanggan

Beberapa scenario menu pelanggan diujikan hasilnya sesuai dengan harapan yang diinginkan.

b. Pengujian Autentikasi User

Pengujian yang dilakukan disini adalah admin membuka halaman administrator dengan memasukan username dan password. Jika username dan passwordnya tidak sesuai dengan tersimpan pada database aplikasi maka login ditolak.

c. Pengelolan Grup Pertanyaan Survei Beberapa proses yang dilakukan pada menu ini adalah penambahan grup, edit dan hapus. Semua fungsinya sesuai dengan yang diharapkan.

d. Pengelolaan Pertanyaan Survei

Pengujian disini melihat fungsi yang ada pada menu ini seperti tambah data, edit, hapus semua sesuai dengan harapan yang diingikan.

\section{KESIMPULAN}

Berdasarkan dari hasil penelitian yang sudah dibahas ditarik beberapa kesimpulan : 
a. Aplikasi Survei pelanggan ini telah memberikan efesiensi komunikasi pelanggan melalui website.

b. Aplikasi ini mempermudah pelanggan menyampaikan keluhannya tentang kualitas pelayanan Perusahaan Daerah Air Minum Kota Bengkulu tanpa harus berkunjung ke kantor tersebut.

c. Dan juga mempermudah bagi Perusahaan Daerah Air Minum untuk mengambil tindakan yang dikeluhkan oleh pelanggan.

\section{UCAPAN TERIMA KASIH}

Kepada Direktur PDAM yang telah memberikan kesempatan untuk penelitian survei kepuasan pelanggan ini.

\section{DAFTAR PUSTAKA}

Arif M. 2016. Rancangan Teknik Industri. Yogyakarta : Deepublish

A. Lubis. 2016, Basis Data Dasar, Yogyakarta: Deepublish.

Bekti H. B., 2015. Mahir Membuat Website dengan Adobe Dreamweaver CS6, CSS dan JQuery. Yogyakarta: Andi Offset 215 hal.

Diana Triningtyas A., 2017. Survey Permasalahan Bimbingan dan Konseling. Jawa Timur : CV. AE Media Grafika.

Hikmah B. A, Supriadi D , 2015. Cara Cepat Membangun Website dari Nol. Yogyakarta : CV. Andi Offset. 100 hal.

Kadir A., 2014. Pengenalan Sistem Informasi Edisi Revisi Yogyakarta : Andi Offset

Ladjamudin Al-Bahra Bin. 2013. Analisisdan Desain Sistem Informasi. Yogyakarta: Graha llmu.

Lamhout Sitorus,. 2015. Algoritma dan Pemograman. Yogyakarta : CV. Andi Offset

MADCOM. 2016. Pemrograman PHP dan MySQL Untuk Pemula. Yogyakarta: C.V Andi.Offset. 152 hal.

$M$ Arif. 2016. Bahan Ajar Rancangan Teknik Industri. Yogyakarta : Deepublish. 218 hal.
Meithiana Indrasari. 2019. Pemasaran Dan Kepuasan Pelanggan. Surabaya : PT Unitomo Press

Nugroho B., 2014. Dasar Pemrograman Web PHP - MYSQL Dengan Dreamweaver. Yogyakarta : Gava Media. 392 hal

Rahmadi Lutfhi. 2013. Tips Membuat Website Tanpa Goding da Langsung. Yogyakarta : CV Andi Offset 56 hal.

Rosa A. S., Salahuddin M., 2015. Modul Pembelajaran Rekayasa Perangkat Lunak (Terstruktur dan Berorientasi Objek).Bandung: Modula.

Rosa A. S., Salahuddin M., 2016. Rekayasa Perangkat Lunak Terstruktur dan Berorientasi Objek. Bandung: Informatika Bandung.

Raharjo Budi, Heryanto. 2014 Modul Pemograman Web Html, Php, \& Mysql. Bandung: Modula

Safaat Nazruddin h. 2012. Pemograman Aplikasi Mobile Smartphone dam Tablet PC berbasis android. Bandung : Informatika

Sugiyono, 2012. Metode Penelitian Bisnis. Bandung: Alfabeta.

Pahlevi Mirza S., 2013. Tujuh Langkah Praktis Pembangunan Basis Data. Jakarta : PT Elex Media KomputindoErstad, O. (2011). Citizens Navigating in Literate Worlds: The Case of Digital Literacy. In M. Thomas (Ed.), Deconstructing digital natives: young people, technology, 